\title{
XIX. An abstract of the characters of Ochsenheimer's Genera of the Lepidoptera of Europe; with a list of the species of each genus, and reference to one or more of their respective icones
}

\author{
J.G. Children F.R.S. L.\&E. F.L.S.
}

To cite this article: J.G. Children F.R.S. L.\&E. F.L.S. (1829) XIX. An abstract of the characters of Ochsenheimer's Genera of the Lepidoptera of Europe; with a list of the species of each genus, and reference to one or more of their respective icones, Philosophical Magazine Series 2, 5:26, 119-126, DOI: $10.1080 / 14786442908674933$

To link to this article: http://dx.doi.org/10.1080/14786442908674933

曲 Published online: 10 Jul 2009.

Submit your article to this journal $\widetilde{3}$

Џll Article views: 2

Q

View related articles $\asymp$ 
of their greatest activity: and whilst we allow that intervals of long repose were necessary for the operations of deposit and formation, we must also confess that they have given place to paroxysms of perhaps not immeasurable activity.

An act like the elevation of the anticlinal line, which formed the basins of London and Hampshire, or the subsidence of these basins, would be alone sufficient to raise a wave that would drown the habitable parts of half a hemisphere. A few such actions coming into play contemporaneously, or in quick succession, are cause sufficient for a deluge. The sagacity of a living geologist has shown that such a deluge was universal; and a little further research only is sufficient to show, that we need not leave our own planet for secondary causes adequate to the purpose: to show also, that the flood which left us the "Reliquiæ Diluvianæ," was the flood of denudation; and that that flood (denudation being in many cases ruled by disruption and devastation from below) went and came upon the earth many days.

Pulborough, Jan. l, 1829.

XIX. An Abstract of the Characters of Ochsenheimer's Genera of the Lepidoptera of Europe; with a List of the Species of each Genus, and Reference to one or more of their respective Icones. By J. G. Grimdren, F.R.S. L. \& E. F.L.S.\&.

[Continued from page 51.].

Genus 38. PSYCHE, Schrank, (Steph.)

Canephore, Hübn. Bombyx, Fab:, Latr.

Legs slender, transparent, scarcely pilose; posterior tarsi with very short spurs at the apex.

Wings in the male elongate, rounded posteriorly, very transparent, slightly hairy; wanting in the females.

Antenna-of the male rather short, bipectinated, the pectinations twisted and very pilose:- of the female very short, simple, submoniliform, the two basal joints very large and robust, the rest small.

Palpi and maxilla none, replaced by a loose tuft of hair.

Head and thorax scarcely pilose, shining: abdomen of the male rather robust, thickly pilose;--of the female naked, rather glossy above, with a woolly mass at the apex : ovipositor exserted, subtruncate*.

Larva inclosed in a cylindrical case, composed of blades of

- Characters from Stephens. Illust. Brit. Ent. II. Haust. p. 79. 
grass, morsels of leaves, bark of trees, \&c. and which it drags about with it by means of the anterior or pectoral feet (hence called sacciferous larvæ), the only ones fit for crawling-the posterior being imperfect.

Pupa elongate: metamorphosis in the larva-case attached to the branches of trees, or other elevated objects. Prior to the change the larva is reversed; so that the imago issues from the posterior aperture. (Ochs.)

Obs. The natural history of the sacciferous insects has for many years engaged the attention of the most distinguished entomologists, and yet much still remains to be done for its perfect elucidation, although many singular and important facts have been discovered respecting them. One of the most remarkable is that of the females occasionally laying fruitful eggs without any previous intercourse with the male: the fact is as unquestionable as it is mysterious, having been confirmed by many experiments conducted with every necessary precaution. The most complete are those of Rossi, an account of which is given in a letter on Psyche apiformis, addressed to the Abbate Mazzola.

I venture to introduce the genus Psyche (which cannot with propriety be arranged with the Tinece, Schaben?) in this place; since, in respect of the perfect male insect, it forms the fittest passage to the next genus (Liparis). Ochs.*

A.-Females apterous, hexapodous : abdomen terminated by a pilose tuft : ovipositor exserted.

\section{Species.}

1. Ps. Pulla, Esp.

2. - Plumella, Ochs. $†$

3. - Nitidella, Hübn..

4. - Pectinella, Fab....

5. - Bombycella, Hübn.

6. - Calvella, Ochs....

7. - Nudella, Ochs.ł..

8. - Glabrella, Ochs...

9. - Politella, Ochs. $\oint$..
Icon.

Hübn. Tineæ, Tab. I. f. 7. (mas.)

Hübn. Samm. auser: Vog. und Schmett. Tab. 47.

Hübn. Tineæ, Tab. I. f. 6. (mas.)

Hübn. Tineæ, Tab. I. f. 5. (mas.)

Hübn. Tineæ, Tab. I. f. 4. (mas.)

Hübn. 'Tineæ, 'Tab. I. f. Э. (mas.)

Hübn. Tinex, Tab. 3J. f. 212. (mas.) Tab. 56. f. 382. (foem.)

* Poda in the Mus. Grace. places them with Tenthredo, and Scopoli, in the Ento. Carniol. with Phryganea.-Ochs.

$+\mathrm{Ps}$. alis rotundatis fuscis, nigro-yenosis.-Ochs. III. 168.

I Ps. alis omnibus albo-cinereis, subhyalinis, albo-ciliatis. - Ochs. III.173. Nov. Sp. Ps. alis anticis oblongis, lividis, immaculatis; posticis cinereis, cilis albidis.-Ochs. IV. 200. 
Ochsenheimer's Genera of the Lepidoptera of Europe. 121

B.-Females vermiform; no visible organs of emotion.

Species.

10. Ps. Hirsutella, Ochs.*

11. - Muscella, Fab. ...

12. - Plumifera, Ochs.†

13. - Apiformis, Rossi .

14. - Viciella, Fab. ....

15. - Villosella, Ochs. . Hübn. Tineæ, Tab. 1. f. 2. (mas.)

16. - Graminella, Hübn. Hübn. Tineæ, Tab. 1. f. 1. (mas.)

\section{Genus 39. LIPARIS, Ochs.}

\section{Laria, Schrank. Hypodyma et Leucome, Hübn.}

Antenne bipectinate, the pectipations in the male very strpng. Maxilles none.

Wings deflexed, rather lightly scaled, generally of one uniform colour, or marked with dark maculæ or bands.

Abdomen, -in the female often furnished at the apex with a large, finely pilose, tuft, with which she covers her eggs when deposited, tearing it from her body for that purpose, by means of the hinder legs.

Larva with hairy tubercles, variegated.

Pupa with small pilose tnfts; changes in a thin web.

$O b s$. All the species enumerated below, unquestionably belong to this genus; the two last, only, differing from the rest, as regards the pupa and its web; but there does not appear to be sufficient reason for assigning them a separate place on that account. (Ochş.)

Species.

Icon.

1. L. Morio, Lipn.‡ ... Ernst, IV. Pl. CXXXIV, f. 179. a-d.

2. - Detrita, Esp. $\ddagger$... Huibn. Bomb.Tab. 16. f.58. (mas.) 59. (fæm.)

3. - Rubea, Fab. .... Hübn.Bomb.Tab.56.f.240.(mas.) Tab, 16. f. 60.61. (foem.) $\oint$

* Ps. alis nigrescentibus, abdomine hirto, fusco.-Ochs. III. 173.

$\uparrow$ Ps. alis angustis, byalinis, corpore atro, hirsuto, antennis plumosis. Ochs. III. 176.

3*P. nigricans, Curtis............ Curtis, Brit. Ent. V. Pl. 213.

This species is not noticed by Ochsenheimer.

I Pentbophera, Germar, Curtis, Steph.

"Antenna inserted on the crown of the head close to the eyes, setaceous, strongly bipectinated in the males, each joint producing two slightly clavate rays, very long and slender towards the centre, pilose, and terminated by a few strong hairs; simple in the females. Maxilla none.

New Series. Vol. 5. No. 26. Feb. 1829. R Rabial 
Species.

Icon.

4. L. Monacha, Linn.* Ernst, IV. Pl. CXXXVII. f. 185. a-i.

5. - Dispar, Linn.† ...

Ernst, IV. Pl.CXXXVIII. f. 186.

6. - Salicis, Linn.f ... $\mathrm{a}-\mathrm{g}$.

Ernst, IV. Pl. CXXXV. f. 181. a-d.

7. - V. nigrum, Fab. $\quad$ Ernst, IV. Pl. CXXXIV. f. 180. $a-g$.

\section{L. Chry-}

Labial palpi cuspidate, nearly concealed by hair, porrected, triarticulate? the basal joint very obscure, 2nd small, 3rd large, oval. Head small. Eyes small, globose, granulated. Thorax large in the males alone. Abdomen sometimes short and truncated in the male, subovate in the female. Wings large and rounded, rarely small and lanceolate in the female. Legs slender. Tibice anterior with a short slender spine on the internal side, the others spurred only at their apex. Tarsi 5-jointed, basal joint the longest, penultimate the smallest. Claws and pulvilli distinct. Larva with 6 pectoral, 8 abdominal, and 2 anal feet, tuberculated, each tubercle producing a bundle of hairs."-Curtis, Brit. Ent. V. 213.

* Psilula, Steph.

"Palpi very hairy, triarticulate; the basal joint nearly half as long as the second, somewhat clavate; the second elongate, clavate; the terminal ovate, acute: maxillae obsolete. Antenna short, acute, very strongly bipectinated in the males, slightly in the females: head small, very pilose : thorax rather short and downy : abdomen slender, and tufted at the apex in the male, rather short and attenuated in the female, with the apex acute and naked: wings deflexed, thickly clothed with scales : legs not very slender; femora and tibice fringed with hairs. Larva elongate, attenuated posteriorly, with fascicles of hair on the back and sides; those behind the head and on the penultimate segment longest. Pupa smooth, with tufts of hair on the segments, the terminal one with an obtuse projection : changes in a loose folliculus."

"This genus differs from the foregoing (Hypogymna) by having the basat joint of the palpi elongate, somewhat triangular and clavate, the terminal acute, and closely allied to the preceding; the female has the abdomen moderately stout, and attenuated posteriorly, with the ovipositor exposed." -Steph. Illust. Brit. Ent. II. 57.

t Hy rogymna, Steph.

" Palpi hairy, short, triarticulate, the basal joint minute, second elongate, subclavate, terminal ovate, obtuse : maxilla obsolete. Antenne short, acute at the tip, very strongly bipectinated in the males, slightly in the females : head minute, with a downy tuft : thorax and abdomen stout, woolly, the latter very robust and obtuse in the female, and terminated by a downy mass, rather attemuated, and furnished with a hairy tuft in the male: wings deflexed, not very densely clothed with scales: legs not very stout; femora and tibice slightly fringed with long hairs. Larva elongate, cylindric, with short, rigid hairs on the back, and elongate fascicles on the sides of the head, and at the tail : pupa sligh ly' hairy, the apex with a truncate projection: it changes in a loose cocoon."-Steph. Mlust. Brit. Ent. II. 55.

f Leucoma, Steph.

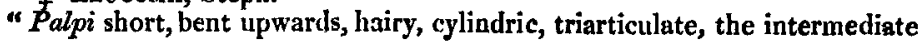


Ochsenheimer's Genera of the Lepidoptera of Europe. 123

\author{
Species. \\ 8. L. Chrysorrhoea, \} Ernst, IV. Pl. CXXXV. f. 182. \\ Linn.* .......... $\}^{\text {a-f. }}$ \\ 9. - Auriflua, Fab.*... Ernst, IV. Pl. CXXXVI. f. 183. \\ a-f.
}

joint longest, the terminal shortest, obtise: maxilla very short. $A n-$ tenne acute, of equal length in both sexes, deeply bipectinated in the males, the pectinations gradually shortened towards the apex, ciliated and furnished with one or two fine setæ at the tip, shortest in the females: head small, hairy, with a distinct fascicle of scales at the base of each antenna : thorax short, woolly : abdomen tufted in the malés, very robust and acute in the females: wings deflexed, rather broad, trigonate, with remote scales : legs robust; femora and tibice slightly fringed with hair. Larva with fascicles of hair on each side, and sometimes with loose dorsal tufts : pupa slightly hairy, enclosed in a loose orbiculate cocoen : eggs enveloped in a fríable silken matter." Steph.l.c. p. 63.

* Portuesia, Steph.

"Palpi very short, descending, slightly hairy, cylindric, triarticulate, the terminal joint exposed; the basal minute, about half as long as the terminal, the intermediate longest : maxilla very short : antenne short, especially in the females, acute, bipectinated in both sexes to the apex, the pectinations shortest in the females: head small, very pilose: thorax and abdomen somewhat robust and woolly : wings deflexed, subtrigonate, thickly clothed with scales : legs robust, short; femora, tibice, and anterior tarsi densely fringed with elongate hairs. Larva with close fascicles of hair down the sides, rather longest on the neck; the back without tufts : pupa slightly hairy, acute, enclosed in a slight folliculus : eggs enveloped in down."-- Steph. Illust. Brit. Ent. II. 65.

Schrank's genus Arctia is quoted by Ochsenheimer as forming part of his genus Eyprepia. Curtis has adopted the genus Arctia, as Stephens has also dune more lately; the former inserting under it the British species, 1. caenosa, Hübn.; 2. V. nigra, Fab.; 3. Salicis, Linn.; 4. chrysorrhcea, Linn.; and 5. phecorrhera, Haw. The first and last species I cannot find noticed at all by Ochsenheimer; the second, third, and fourth, form part of his genus Liparis (q. v. ut sup.). Stephens has adopted Hübner's genns Leucoma to receive $V$. nigra and Salicis; and has created a new one, Porthesia, for chrysorrhoea and another; and his genus Arctia consists of Caja, matronila, villica, Hebe, purpurea, and aulica, all of them Eyprepice of Ochsenheimer. He has, moreover, created another new genus, Lalia, to receive Hübner's Bombyx canosa, and which he characterizes as follows:

$$
\text { “ LELIA, Steph. }
$$

“ Palpi elongate, projecting, very hairy beneath, the last joint exposed; triarticulate, the basal and terminal joints very minute, the second considerably elongated : maxilla distinct. Antenne moderate, shortest in the females, deeply bipectinated in the males the pectinations terminating abruptly at the tip, and very short in the female, each pectination ciliated, and furnished at its apex with three or fonr divergent bristles : head small, pilose; thorax not crested, pilose : wings deffexed, rather narrow, trigonate, sparingly clothed with scales : abdomen rather elongated, and stout, slightly tufted : legs moderate; the femora and tibiae fringed with elongate hairs. Larva hairy, with four, compact dorsal tufts, and one at the tail, and two elongate fascicles at the neck: pupa slightly pilose, acute at the tip, enclosed in an elongate, compact, yellow folliculus."

1. La. Conosa, Hubn. .... C Curtis, Brit. Ent. II. Pl. 68. đ, o and Larva. 
Genus 4.0. ORGYIA, Ochs.

Laria, Schrank. Dasychiræ, Hübn.

Legs, anterior hairy, stretched out forwards, when at rest*. Antenna,-in the male strongly bipectinate; in the female only slightly feathered.

Haustellum very short.

Wings deflexed.

Larva, with hairy tufts on the head, back and posterior portions of the body.

Pupa hairy; the metamorphosis takes place in a double web mixed with hairs $\dagger$.

Species.

Icon.

1. O. Pudibunda, Linn. $\ddagger$ Ernst, IV. Pl. CLX. f.207. a-g.

2. - Abietis, Hübn.... Hübn. Bomb. Tab. 21, f. 82 . (mas.) 83. (foem.)

3. - Fascelina, Linn. $\ddagger$ Ernst, IV.Pl. CLXI.f. 209. a-h.

* Hence the name of the genus, from ogery, cxtendo, and yurou, membrum. + Stephens has adopted Ochsenheimer's genus Orgyia, for his two last species, Gonostigma, and Antiqua, with the following characters:

"Palpi short, compact, hairy, biarticnlate; the basal joint small, the terminal large, broad, ovate, subacute: maxillce obsolete. Antenne short, deeply bipectinated in the males, abruptly terminated: serrated in the females, each serrature producing a bristle : head small, hairy : thorax slender, not crested: wings deflexed, short, triangular, or wanting: legs rather stout, anterior elongated; the femora and tibice of all, and the tarsi of the anterior, fringed with elongate hairs. Larva with distinct fascicles of hair on the sides, and several dorsal tufts; two or more, composed of capitate hairs, on the sides of the body and head; one on the penultimate joint, and some shorter ones at the apex: pupa slightly pilose, with an acute spine at the tip: folliculus ovate, of a very loose texture."-Illust. Brit. Ent. Haust. II. 60.

The females of this genus are apterous.

f Dasychira, Hüibn. Steph.

"Palpi very short, hairy, triarticulate; the basal joint about one-third the length of the second, and more slender, the terminal ovate, acute: maxilla obsolete. Antennee short, acute at the apex, thickly bipectinated, especially in the male; the pectinations deeply ciliated, and shortest in the females: head small, hairy: thorax rather stout, not crested: abdomon somewhat robust, especially in the females, woolly beneath : wings deflexed, elongate, thickly and densely covered with scales: legs short, stout, pilose; femora and tibice, and exterior tarsi fringed with long hairs. Larva very hairy, with several compact, truncated tufts on the back, and another on the tail : pupa hairy, enclosed in an ovate folliculus, its posterior extremity with an acute projection."-Steph. Illust. Brit. Ent. Haust. II. 58.

Dasychira, Stephens adds, differs "from Orgyia, by the acuteness of the apex of the antenux, and triarticulate palpi. The species of this genus considerably resemble those of Cnethocampa."-(Gastropacha, Ochs.) Steph. l. c. 
Icon.

4. O. Selenitica, Hübn. Hübn. Beitr. II. B. 3. Th. I. Taf. fig. A. (fœm.)

Hübn. Bomb.Tab. 20.f. 79.(mas.) 80. (fom.)

5. - Gonostigma, Fab.* Ernst, IV. Pl. CLXIII. f. 212. a-h.

6. - Antiqua, Linn.*.. Ernst, IV. Pl. CLXII. f. 211. $a-f$.

Genus 4.1. PYGAERA, Ochs.

Laria, Schrank. Pygera, Steph.

Melaloph $x$, Hübn. Clostera, Hoffmansegg, Steph.

Antenne bipectinate.

Haustellum short.

Wings lie close to the body; anterior with a coloured spot at the apex, and bright curved transverse lines.

Head and thorax with a velvety striga.

Abdomen long, tufted at the extremity (tuft bifid in the male); posterior portion elevated when at rest $\uparrow$.

Legs, anterior extended.

Larva slightly pilose; with a hairy tubercle on the fourth and last segment.

Pupa, with the extremity aculeated, changes in a close web, enveloped in leaves.

Obs. Ochsenheimer confesses that it is difficult to justify the placing the sixth species (Bucephala) with the rest of his Pygera, since the setose antennæ of the females, the fore feet extended when at rest, and the mode of metamorphosis, are opposed to that arrangement. He has consequently separated that species and the next (Bucephaloides) from the five preceding, under a third family of the genus C. Stephens places Bucephala alone in the genus Pygara, though his generic characters differ little from those of Ochsenheimer, as far as the latter go. Four other species of our author's Pygarce (composing his family B. of this genus) are placed by Stephens in Hoffmansegg's genus Clostera, which he adopts, as will be seen presently. To the preceding generic characters of Ochsenheimer, I add, in a note hereafter, those of Pygara as given by Stephens: the characters of the genus Clotexa will also be found below.

* Genus, Orgyia, Steph.

+ Hence the name of the genus, from $\pi v r n$, anus, and at; $\omega$, lollo. 
126 Ochsenheimer's Genera of the Lepidoptera of Europe.

Species.

Icon.

Fam. A. 1. Py. Timon, Hübn. Bomb.Tab.22.f.86. (mas.)

Hübn.

FAM. B. 2. Anastomosis, \} Ernst, IV. Pl. CLXIV. f. 213. Linn.* $\}$ a-i.

3. Py. Reclusa, Fab.*... Ernst, IV. Pl. CLXV. f. 216. $a-e$.

4. - Anachoreta, Fab." Ernst, IV. Pl. CLXV. f. 214.

5. - Curtula, Linn.*... Ernst, IV. Pl. CLXV. f. 215. $\mathrm{a}-\mathrm{c}$.

FAM. C. 6.Bucephala,Linn. $†$ Ernst, V. Pl. CLXXXV. f. 240. a-h.

6. Py. Bucephaloides, Ochs.Hübn. Bomb.Tab.63.f.267.(mas.) 268. (fœm.)

* Clostera, Hoffmansegg. Steph.

"Palpi short, porrect, slightly ascending aud pilose, "triarticulate, the apical joint minute. Antenne short, curved, pectinated to the apex in both sexes, in the males especially, with a fascicle of scales at the base : head very minute, concealed beneath the thorax, the latter robust, strongly crested, with a central, coloured, longitudinal patch : abdomen moderate, the apex suddenly attenuated, with a bifid tuft : wings, anterior elongate, the hinder margin entire, the apex with a more or less discoloured patch; posterior entire; tibice with spurs. Larve slightly pilose, with a tubercle on the fourth, and another on the anal segment, posterior legs perfect : pupa folliculated." - Steph. Illust. Brit. Ent. Haustell. II. p. 12.

The distinguishing characters between this genus and Pygara, Stephens states to be the brevity of the antennæ of the former, which are pectinated in both sexes and distinctly curved; the form of the thoracic crest, and the longitudinal patrh thereon; the deeply inserted, minute head, and the integrity of the posterior margin of the anterior wings. The larva differs from that of Pygara in being very slightly pilose, and in having the fourth and anal segment, tuberculated above,-Steph. l. c.

+ Pygrar, Steph.

"Palpi short, porrect, densely pilose, two-jointed, basal joint incurved, second reversed, obtuse. Antennae rather long, pectinated in the male, each articulation producing a duplex cilia on each side, the apex simple; setaceous in the female; head small, with a bifid crest at the base of the antennæ : thorax stout, strongly crested, with two elevated lateral strigæ : abdomen long, the apex with an undivided tuft : wings, anterior elongate, triangular, the apex with a large, rounded, discoloured patch, the hinder margin denticulated; posterior entire : tibice with spurs. Larva cylindric, pilose, without elevated appendages, the anal legs perfect: pupa subterranean." - Steph. Illust. Brit. Ent. Haustellata, II. p. 11.

[To be continued.] 